\title{
Time to light up the NBC airwaves
}

The NBC is a shadow of its former self. The provincial Kundu service, following years of neglect, has become an unproductive shambles. The flagship Karai service has a weak signal. And the 'cash cow' Kalang has contributed little.

\section{By IAN BODEN}

NEW APPOINTMENTS announced in September 1995 by the Papua New Guinea Government included a move by former United Nations Permanent Representative Renagi Lohia to the chairmanship of the National Broadcasting Commission. Lohia has an academic and public service background, including a number of administrative and organisational roles. In the mid-1980s, he was chairman of the Public Services Commission, at a time of great change and reorganisation within the commission, and the national public service. This administrative expertise will stand the incoming NBC chairman in good stead, for the task ahead of Lohia and his commissioners is a daunting one.

The NBC is a shadow of its former self. The provincial Kundu service, following years of neglect, has become an unproductive shambles, with far too many provincial stations off the air. The original intentions of this service were to provide a real grassroots link, and an information and entertainment service for the bulk of the rural community.

The flagship Karai service, which should be clearly heard throughout PNG, West Irian, the Solomon Islands, and even the Torres Strait and Cape York peninsula, now sends out a signal unheard in much of Papua New Guinea. The once innovative and highly respected NBC news service has been compromised, both through lack of resources and lack of initiative, middle management skills, and plain old-fashioned journalistic dedication.

Housing for NBC employees outside Port Moresby is universally disgraceful and many provincial studios are a standing joke, ill-equipped, tumbledown and, in some cases, the subject of health closure orders. 


\section{IAN BODEN}

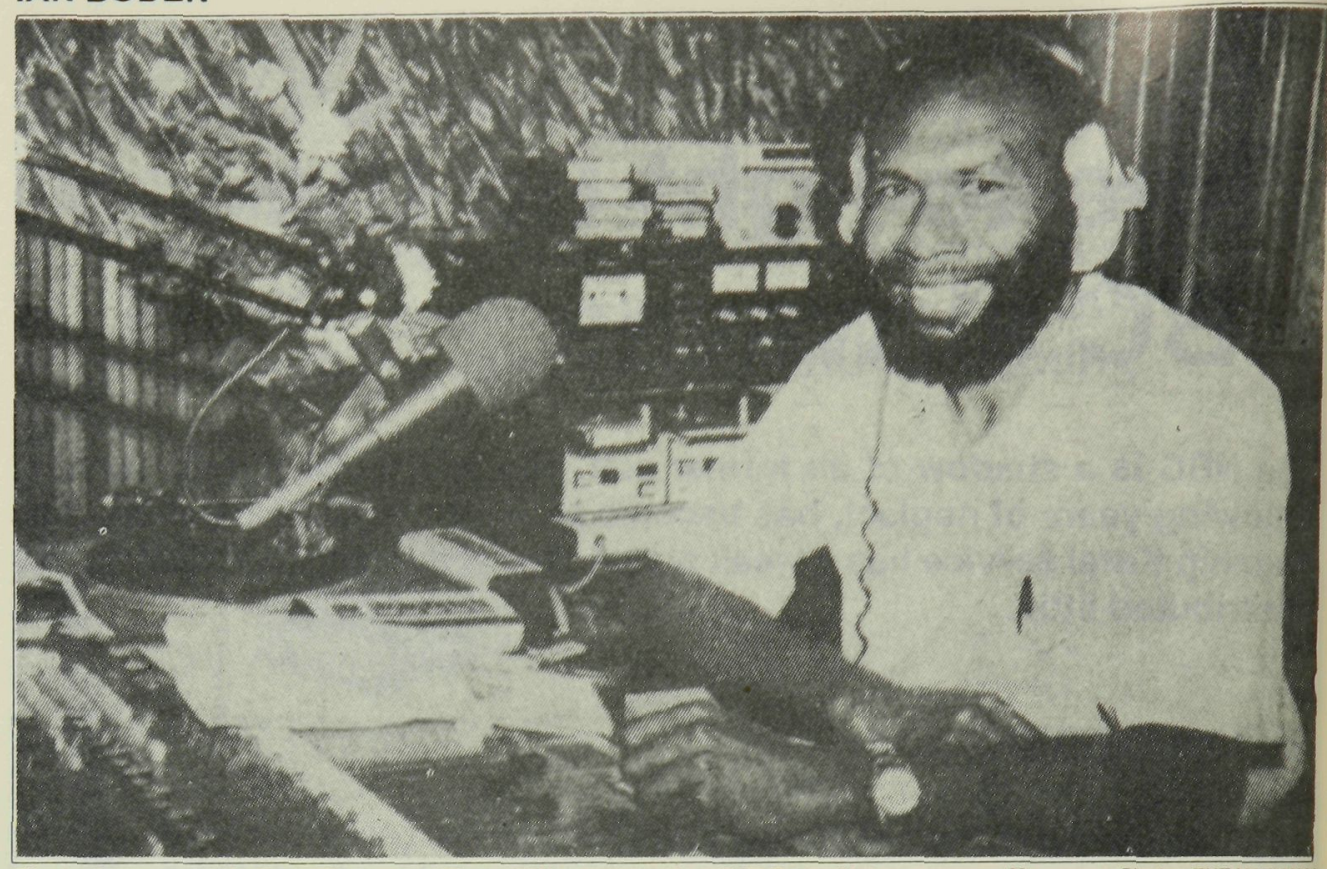

Flagging morale? ... Benson Topatiliu, a senior NBC radio personality.

Photo: THE NATIONAL

Kalang FM, intended as a cash cow for the NBC, appears to have contributed little financially to the commission, in spite of its access to premises within Broadcasting Haus at Five Mile, and in spite of its use of NBC news-gathering and other services. In my opinion, Kalang should be sold off to the highest bidder, and made to perform in direct commercial competition with others, such as Nau FM.

Real money should be invested in restructuring the Kundu service. I believe the size of this service can be reduced by two-thirds, while its potential audience can be increased by a similar margin at the same time. Radio technology has come a long way indeed since the establishment of the Kundu service in 1973. Technically, it is no longer necessary to have fully operational radio stations in each province. Four regional stations, purpose-built and equipped with up-tothe-minute technology, would be capable of meeting all the current network's requirements, and re-establishing the role and importance of the NBC throughout Papua New Guinea.

As for the flagship shortwave service, Karai must be returned to its former eminence as the radio spokesman for the nation. No other media currently operating in PNG can come anywhere near the amount of coverage that can be provided by an efficiently operating NBC.

As for funding, there is a multitude of means available to the commission to generate income. These include product marketing, along the lines of the 48 PACIFIC JOURNALISM REVIEW 2:1 1995 
enormously successful operations of the BBC and $\mathrm{ABC}$ shops; a commercial run transcription service producing cassettes of the NBC's best programs; traditional music for sale to overseas collectors; and even a monthly current affairs summary that could be sold to the Education Department and the universities for use in the schools and institutions.

Perhaps the greatest hope for the NBC lies in a small amendment passed earlier in 1995 through Parliament, which at last brought about the separation of the functions of chairman and chief executive. The real power for change and progress will lie in the hands of the chief executive, and the appointment to this position must be made as a matter of priority.

The commissioners must be fearless, and to avoid any suggestion of political bias in this appointment it must go to the person most qualified to rescue the NBC and develop its enormous potential. I wish the incoming chairman the best of luck in his endeavours - he is certainly in need of it!

$\square$ Ian Boden is a broadcaster and journalist who has worked in Papua New Guinea for more than 30 years, including 15 with the NBC and its predecessor, the $A B C$. He has since then been press secretary to former PNG Prime Minister Rabbie Namaliu; Opposition leaders Sir Michael Somare, Jack Genia and Chris Haiveta; and he is Artscape columnist for The National. This article was originally published in The National of 13 October 1995 following an earlier series on NBC's problems published in June.

\section{OUT NOW! THE BOOK$$
\text { THAT SHOCKED OVER }
$$$$
\text { NEWSMEN'S DEATHS! }
$$

East Timor: The Balibo Incident in Perspective, by James Dunn, was released on the 20th anniversary of the murder of five Australian-based journalists in Balibo, East Timor. Sent to cover the secret invasion of East Timor by Indonesia, the journalists were killed on 16 October 1975 because they witnessed and filmed an across-border raid by 1300 Indonesian troops, supported by tanks, helicopters, and a naval bombardment. Priced just $A \$ 5$ if you order now.

Mail order: Australian Centre for Independent Journalism, University of Technology, Sydney, PO Box 123, Broadway, NSW 2007, Australia. Tel: (612) 330 2488. Fax: (612) 2812976 